\title{
Prevalence of Hepatitis E Virus Infection Among Blood Donors in the Eastern Province of Saudi Arabia
}

\author{
Reem A Al Dossary (ID) \\ Awatif N Alnafie ${ }^{2}$ \\ Salma Ali Aljaroodi (iD \\ Jawad Ur Rahman (ID) \\ Basavaraj C Hunasemarada' \\ Khaled R Alkharsah (D) \\ 'Department of Microbiology, College of \\ Medicine, Imam Abdulrahman Bin Faisal \\ University (IAU), Dammam, Saudi Arabia; \\ ${ }^{2}$ Department of Pathology, College of \\ Medicine, King Fahad Hospital of the \\ University, Imam Abdulrahman Bin Faisal \\ University, Dammam, Saudi Arabia
}

Correspondence: Khaled R Alkharsah Department of Microbiology, College of Medicine, Imam Abdulrahman Bin Faisal University, P.O. Box 1982, Dammam,

3|44I, Saudi Arabia

Tel +966-13 3331053

Email kalkharsah@iau.edu.sa
Purpose: Hepatitis E virus (HEV) causes acute hepatitis in humans and constitutes a major problem for immunocompromised patients, patients with hematological diseases, and pregnant women. It is transmitted mainly through fecal oral route; however, transmission through blood and blood products is reported globally and becoming a health concern. We sought to determine the prevalence of HEV among blood donors in the Eastern Province of Saudi Arabia using molecular as well as serological assays to assess the safety of blood transfusion and the need for HEV screening among blood donors.

Patients and Methods: A total of 806 whole blood samples were collected from blood donors between May and November 2020 and tested for anti-HEV IgG and IgM antibodies by ELISA and for HEV RNA by RT-PCR.

Results: The overall seroprevalence of HEV IgG antibodies was $3.2 \%$ with no statistically significant difference between the non-Saudis $(3.28 \%$ ) and Saudis $(3.17 \%)$ ( $p$ value 0.929 ) or between males $(3.14 \%$ ) and females $(4.88 \%)$ ( $\mathrm{p}$ value 0.527$)$. None of the IgG positive individuals had IgM antibodies. HEV RNA was not detected in any of the blood donors.

Conclusion: HEV seroprevalence is low among blood donors in the Eastern Province of Saudi Arabia and may constitute minimal risk for transfusion associated infections.

Keywords: HEV, IgG, IgM, seroprevalence, ELISA, RT-PCR

\section{Introduction}

Hepatitis E virus (HEV) is a single-stranded positive sense RNA, non-enveloped, icosahedral virus that belongs to the genus orthohepevirus of the family Hepeviridae. Like other hepatitis viruses, members of this genus affect the liver and cause acute hepatitis in humans and various mammals. Immunocompromised patients and pregnant women are also a cause of chronic hepatitis. ${ }^{1,2}$ A key feature of HEV, unlike other hepatitis viruses, is its ability to infect animals as well. Phylogenetically, the genus Orthohepevirus A is divided into eight genotypes (HEV 1-8) with different host specificity and geographical localization. HEV-1 and HEV-2 are mostly associated with human infection, while HEV-3 and HEV-4 can infect humans and animals, such as swine, deer, goats, Bottlenose dolphins and boars. $^{3-5}$ HEV-5 and HEV-6 were found in wild boar in Japan, while HEV-7 and HEV-8 have only been isolated from camels in China. ${ }^{6}$ Geographically, genotype 1 is most commonly reported in the countries of Asia and Africa, while genotype 2 is most common in Mexico, Nigeria, and Chad. ${ }^{3}$ Genotype 3 is limited to Japan, Korea, and Taiwan, while genotype 4-8 is restricted to Asia., 3

The first epidemic of HEV infection was reported in India as icteric hepatitis in 1955, after which the oral route of infection was documented in a Russian military 
camp in $1990 .^{7,8}$ Although HEV infection is mostly selflimiting and can cause asymptomatic disease, infection of immunocompromised, thalassemic, HIV patients, and pregnant women can cause mild forms of hepatitis, extrahepatic manifestations, and death in some cases. ${ }^{9}$

$\mathrm{HEV}$ infection is mostly ecologically dependent and is associated with travel history to endemic regions or low sanitary conditions, involving water-borne and fecal oral routes as the predominant route of transmission. ${ }^{9}$ However, evidence of HEV transmission through blood and plasma has been reported globally. ${ }^{7,10-13}$ According to a report from the World Health Organization (WHO), about 118.2 million blood donations were collected in 118 countries globally in the year 2013, and nearly 21 million blood components were transfused annually in the USA alone. ${ }^{14}$ But HEV is not included in routine testing for pathogens before blood transfusion. A number of surveillance studies have been done to detect the prevalence of $\mathrm{HEV}$ in blood donors, indicating that the sero-positivity of HEV among blood donors ranges from $2 \%$ to $49 \%$ in different parts of the world. ${ }^{4,9,11-55}$ Some studies reported active viremia in blood donors, indicating a direct risk to blood or blood components recipients. $^{7,12,18,21-24,29,30,32,34-41,45,46,48,52-54,56-58}$ Table 1 summarizes studies in the literature concerning HEVseroprevalence among blood donors.

The transfusion-related $\mathrm{HEV}$ transmission, which is reported in several studies, strongly suggests the need for HEV screening of donated blood. No study from Saudi Arabia so far has investigated the prevalence of $\mathrm{HEV}$ RNA in blood donors to estimate the risk of HEV transmission from blood transfusion. In our study, we sought to determine the prevalence of HEV among blood donors in the Eastern Province of Saudi Arabia using molecular as well as serological assays.

\section{Materials and Methods}

\section{Inclusion and Exclusion Criteria}

All blood donors attend the blood bank section of the Laboratory department of king Fahd Hospital of the University of Al-Khobar between May 15 and November 31, 2020. Blood donors who did not gave consent to participate in the study were excluded.

\section{Sample Collection}

A total of 806 blood samples were collected in EDTA tube from the blood donors attending the blood bank section of
King Fahd hospital of the University (KFHU) in AlKhobar, Saudi Arabia. Blood samples were centrifuged, then the plasma was separated and stored at $-80^{\circ} \mathrm{C}$. Written ethical consent was taken from the participating volunteers, including information on their age, gender, and nationality. All the volunteers were informed about the purpose of study in accordance with the declaration of Helsinki.

Ethical approval for the study was obtained from ethical committee of the Institution Review Board (IRB) at Imam Abdulrahman Bin Faisal University (IAU) (number IRB-2020-01-149).

\section{Serological Tests}

All plasma samples were tested qualitatively for anti-HEV antibodies of $\mathrm{IgG}$ type using an indirect enzyme-linked immuno-sorbent assay, Human Hepatitis E Virus IgG (HEV IgG) ELISA Kit (Abbexa Ltd, Cambridge, UK). ${ }^{60}$ Positive HEV IgG plasma samples were further tested for Anti-HEV IgM antibodies against Orthohepevirus A genotypes, using Human Hepatitis E Virus IgM (HEV IgM) ELISA Kit (Abbexa Ltd, Cambridge, UK) following the manufacturer's instruction. ${ }^{60,61}$

The HEV IgG \& IgM ELIZA plates are coated with Recombinant HEV ORF-2/ORF-3 antigen and Mouse-anti -human IgM ( $\mu$ chain), respectively. These ELIZA kits can detect IgG/IgM antibodies against Orthohepevirus A genotypes. The sensitivity and specificity of HEV-IgM (abx055720) is $99.6 \%$ and $99.2 \%$, while HEV-IgG (abx364866) is $99.5 \%$ and $99.3 \%$, respectively.

\section{NAT Testing}

RNA was extracted from plasma samples using QIAamp Viral RNA mini kit (Qiagen, Hilden Germany), as per the manufacturer's instructions. All samples were spiked with internal control from the employed detection kit. All plasma samples were tested for HEV RNA using RealStar HEV RTPCR Kit 2.0 (Altona Diagnostics GmbH, Hamburg, Germany). ${ }^{62}$ The assay was run on the Applied Biosystem QuantStudio $^{\text {TM }}$ 5-Realtime PCR system (Thermo Fisher Scientific, MA, USA). Quantification standards provided with the kit were used with each run. The standards are designed in accordance with the first World Health Organization International Standard for Hepatitis E Virus RNA Nucleic Acid (NAT)-Based Assays (PEI code 6329/ $10)$. The analytical sensitivity of the kit is $95 \%$. It specifically detects all relevant genotypes of HEV and does not cross-react with viruses causing similar symptoms. ${ }^{62}$ 
Table I Summary of the HEV Seroprevalence Studies in Blood Donors in Multiple Geographical Areas

\begin{tabular}{|c|c|c|c|c|c|c|c|c|c|}
\hline \multirow[t]{2}{*}{ Continent } & \multirow[t]{2}{*}{ Country } & \multirow[t]{2}{*}{$\begin{array}{l}\text { Year and Study } \\
\text { Duration }\end{array}$} & \multicolumn{2}{|c|}{ HEV IgG Seroprevalence } & \multicolumn{2}{|c|}{$\begin{array}{l}\text { HEV IgM } \\
\text { Seroprevalence }\end{array}$} & \multicolumn{2}{|l|}{ HEV Viremia } & \multirow[b]{2}{*}{ Ref } \\
\hline & & & $\begin{array}{l}\text { Sample } \\
\text { Size }\end{array}$ & \% Positive & $\begin{array}{l}\text { Sample } \\
\text { Size }\end{array}$ & \% Positive & Sample Size & \% Positive & \\
\hline \multirow[t]{19}{*}{ Europe } & Central Italy & $\begin{array}{l}\text { Feb-Mar } 2013 \\
\text { Feb-Mar } 2014\end{array}$ & 198 & 3.5 & 198 & 1.01 & 198 & 0.5 & [15] \\
\hline & Central Italy & Feb-March 2014 & 313 & 49 & 313 & 0.6 & 313 & 0.6 & [46] \\
\hline & Overall Italy & $2015-2016$ & 10,011 & 8.7 & 10,011 & 0.4 & 10,011 & 0 & [47] \\
\hline & Ireland & Dec 2013-Jun 2014 & 1076 & 5.3 & 57 & 2 & 24,985 & 0.02 & [54] \\
\hline & Serbia & 2010 & 200 & 15 & ND & ND & 200 & 0 & [55] \\
\hline & Spain & Jun-Dec, 2013 & 1082 & 19.96 & 216 & 13 & 9998 & 0.03 & [58] \\
\hline & Bulgaria & Jun-Oct, 2020 & 555 & 25.9 & ND & ND & ND & ND & [69] \\
\hline & Germany & $2009-2010$ & ND & ND & ND & ND & 1185 & 1.18 & {$[31]$} \\
\hline & Germany & Jul-Sept 201I & 349 & 6.3 & 349 & 4.3 & 16,125 & 0.08 & [32] \\
\hline & France & Nov-2012-14 & 183 pools & 175 pools & $\begin{array}{l}175 \\
\text { pools }\end{array}$ & 2 pools & 53,234 & 3.94 & [35] \\
\hline & France & $\begin{array}{l}\text { Sept,2003-May, } \\
2004\end{array}$ & 512 & 52.5 & ND & ND & ND & ND & [36] \\
\hline & Southern France & Oct $01-14,2011$ & 3,353 & 39.1 & 3353 & 3.31 & $591^{c}$ & 0.16 & [68] \\
\hline & Paris & Jan I2-Feb 13, 2015 & 11 & 45.45 & 11 & 36.36 & 25,637 & 0.04 & [37] \\
\hline & Upper Austria & Feb 20I3-Apr 2014 & 1203 & 13.55 & 7 & 6 & 58,915 & 0.01 & [34] \\
\hline & $\begin{array}{l}\text { UK/ Southeast } \\
\text { England }\end{array}$ & $\begin{array}{l}\text { Oct } 8,2012- \\
\text { Sep } 30,2013\end{array}$ & 79 & 29 & 79 & 29 & $\begin{array}{l}225 \\
000\end{array}$ & 0.04 & [7] \\
\hline & Netherland & Jan 2013-Dec 2014 & 45 & 24 & ND & ND & 59,474 & 0.0069 & [39] \\
\hline & Netherland & $\begin{array}{l}\text { Nov 20II-Jan } 2012 \\
\text { Apr-May } 2012 \\
\text { Mar-20II (3Days) }\end{array}$ & 5239 & 26.7 & $140 \mid$ & 3.5 & 45,415 & 0.028 & [40] \\
\hline & UK/ Scotland & $\begin{array}{l}\text { 2004-2008 } \\
\text { 2nd set 2012 }\end{array}$ & $\begin{array}{l}1559 \\
528\end{array}$ & $\begin{array}{l}4.7 \\
5.7\end{array}$ & $\begin{array}{l}1559 \\
528\end{array}$ & $\begin{array}{l}0 \\
0\end{array}$ & 43,560 & 0.0069 & [29] \\
\hline & UK/ Scotland & $\begin{array}{l}\text { Aug } 2014 \text { to Sept } \\
2015 \\
\text { Feb } 2016-\text { Feb } 2017 \\
\text { Mar-May } 2017\end{array}$ & 1714 & 6.1 & 38 & 21.05 & 94,302 & 0.04 & [30] \\
\hline \multirow[t]{4}{*}{ Africa } & Egypt & $\begin{array}{l}\text { Sept, 2005- Sept } \\
2006\end{array}$ & ND & ND & 760 & 0.45 & $3^{\mathrm{a}}$ & $66.66^{a}$ & [21] \\
\hline & $\begin{array}{l}\text { Egypt/ Dakahlia } \\
\text { Governorate }\end{array}$ & Jan 2017-Jan 2018 & 200 & 25 & 200 & 5 & 200 & 3 & [22] \\
\hline & Sudan & Apr-Jul, 2014 & 90 & 26.7 & ND & ND & ND & ND & [26] \\
\hline & Ghana & Unknown & 239 & 4.6 & 239 & 5.9 & 239 & 0 & [51] \\
\hline
\end{tabular}


Table I (Continued).

\begin{tabular}{|c|c|c|c|c|c|c|c|c|c|c|}
\hline \multirow[t]{2}{*}{ Continent } & \multirow{2}{*}{\multicolumn{2}{|c|}{ Country }} & \multirow[t]{2}{*}{$\begin{array}{l}\text { Year and Study } \\
\text { Duration }\end{array}$} & \multicolumn{2}{|c|}{ HEV IgG Seroprevalence } & \multicolumn{2}{|c|}{$\begin{array}{l}\text { HEV IgM } \\
\text { Seroprevalence }\end{array}$} & \multicolumn{2}{|l|}{ HEV Viremia } & \multirow[b]{2}{*}{ Ref } \\
\hline & & & & $\begin{array}{l}\text { Sample } \\
\text { Size }\end{array}$ & \% Positive & $\begin{array}{l}\text { Sample } \\
\text { Size }\end{array}$ & \% Positive & Sample Size & \% Positive & \\
\hline \multirow[t]{18}{*}{ Asia } & \multicolumn{2}{|l|}{ Nepal } & Feb-Mar 2014 & 581 & 9.5 & 581 & 4.6 & $27^{\mathrm{a}}$ & 1.54 & [23] \\
\hline & \multicolumn{2}{|c|}{ Pakistan } & Jan-Jun 2020 & 5230 & 3.49 & 5230 & 2.04 & $107^{\mathrm{a}}$ & 0.70 & [24] \\
\hline & \multicolumn{2}{|c|}{$\begin{array}{l}\text { India, Northern } \\
\text { region }\end{array}$} & $\begin{array}{l}\text { Jun-Jul, } 2016 \\
\text { Nov-Dec, } 2016\end{array}$ & 633 & 60.5 & ND & ND & 1799 & 0 & [44] \\
\hline & \multicolumn{2}{|c|}{ India, Pune, } & Jan-Aug, 2017 & 2447 & 17.70 & 2447 & 0.20 & $5^{\mathrm{a}}$ & 40 & [45] \\
\hline & \multicolumn{2}{|c|}{ Philippines } & Unknown & 85 & 11.8 & 85 & 2.4 & ND & ND & [25] \\
\hline & \multicolumn{2}{|c|}{ Thailand } & Oct-Dec 2015 & 26 & $\begin{array}{l}23.08 \text { Emurium } \\
34.6 \text { wantai }\end{array}$ & 26 & $\begin{array}{l}7.69 \\
\text { Emurium } \\
0 \text { Wantai }\end{array}$ & 30,115 & 0.086 & [4I] \\
\hline & \multicolumn{2}{|l|}{ China } & Dec 2002-Oct 2008 & 44,816 & 32.60 & 44,816 & 0.94 & $420^{c}$ & 7.14 & [48] \\
\hline & \multicolumn{2}{|l|}{ China } & Jan-Dec, 2012 & 816 & 21.1 & 816 & 0.5 & 816 & 0 & [49] \\
\hline & \multicolumn{2}{|c|}{$\begin{array}{l}\text { East China, Jiangsu } \\
\text { Province, }\end{array}$} & Jan-Jun, 20II & 486 & 23.3 & ND & ND & ND & ND & [79] \\
\hline & \multicolumn{2}{|l|}{ Japan } & $2004-2014$ & 36 & 19.44 & 36 & 5.5 & 620,140 & 0.007 & [52] \\
\hline & \multicolumn{2}{|c|}{ Cambodia } & Jul-Aug 2014 & 301 & 28.2 & 301 & 0.3 & $301^{\mathrm{a}}$ & 0.3 & [53] \\
\hline & \multirow[t]{3}{*}{$\begin{array}{l}\text { Saudi } \\
\text { Arabia }\end{array}$} & $\begin{array}{l}\text { Al- } \\
\text { Qassim }\end{array}$ & Jan-Apr, 2019 & $\begin{array}{l}\text { Total: } \\
\text { I078 } \\
\text { Saudis: } \\
85.7 \\
\text { Non- } \\
\text { Saudis: } \\
\text { I4.3 }\end{array}$ & 5.7 & 1078 & 1.3 & ND & ND & [65] \\
\hline & & Jeddah & 1995 & 593 & 16.9 & ND & ND & ND & ND & [42] \\
\hline & & Makkah. & Mar-Aug, 2009 & 900 & $\begin{array}{l}18.7 \\
\text { Saudis:15.18 } \\
\text { NonSaudi:23.32 }\end{array}$ & 900 & $\begin{array}{l}4.3 \\
\text { Saudis: } 4.3 \\
\text { Non-Saudi: } \\
4.4\end{array}$ & ND & ND & [43] \\
\hline & \multicolumn{2}{|c|}{ UAE-Abu-Dubai } & Feb-Apr, 2015 & 318 & 10.69 & ND & ND & ND & ND & [17] \\
\hline & \multicolumn{2}{|l|}{ Qatar } & Jun 2013-May 2016 & 5854 & 20.5 & 5854 & 0.58 & $34^{\mathrm{a}}$ & $11.7^{\mathrm{a}}$ & [18] \\
\hline & \multicolumn{2}{|c|}{$\begin{array}{l}\text { Iran/Central } \\
\text { province }\end{array}$} & Sept, 2012 & 530 & 14.3 & ND & ND & ND & ND & [19] \\
\hline & \multicolumn{2}{|c|}{ Iran/Khuzestan } & May-Dec 2005 & 400 & 11.5 & ND & ND & ND & ND & [20] \\
\hline \multirow[t]{3}{*}{ Australia } & \multicolumn{2}{|c|}{ Australia } & $\begin{array}{l}\text { May 16- Dec 02, } \\
2016\end{array}$ & 1 & 100 & 1 & 100 & $74,|3|$ & 0.0013 & [80] \\
\hline & \multicolumn{2}{|c|}{ Australia } & Sept-Oct 2014 & 1 & 0 & 1 & 0 & 14,799 & 0.0068 & [38] \\
\hline & \multicolumn{2}{|c|}{ New Zealand } & $\begin{array}{l}\text { Nov II, 2014-Mar } \\
10,2015\end{array}$ & 1013 & $\begin{array}{l}9.7 \\
8.1\end{array}$ & ND & ND & 5103 & 0 & [27] \\
\hline
\end{tabular}

(Continued) 
Table I (Continued).

\begin{tabular}{|c|c|c|c|c|c|c|c|c|c|}
\hline \multirow[t]{2}{*}{ Continent } & \multirow[t]{2}{*}{ Country } & \multirow[t]{2}{*}{$\begin{array}{l}\text { Year and Study } \\
\text { Duration }\end{array}$} & \multicolumn{2}{|c|}{ HEV IgG Seroprevalence } & \multicolumn{2}{|c|}{$\begin{array}{l}\text { HEV IgM } \\
\text { Seroprevalence }\end{array}$} & \multicolumn{2}{|l|}{ HEV Viremia } & \multirow[b]{2}{*}{ Ref } \\
\hline & & & $\begin{array}{l}\text { Sample } \\
\text { Size }\end{array}$ & \% Positive & $\begin{array}{l}\text { Sample } \\
\text { Size }\end{array}$ & \% Positive & Sample Size & \% Positive & \\
\hline \multirow{4}{*}{$\begin{array}{l}\text { North } \\
\text { America }\end{array}$} & USA & Jul 20-Aug 29, 2015 & 3 & 33.33 & 3 & 0 & $|28,02|$ & 0.002 & [56] \\
\hline & USA & Feb-Jul, 2013 & 4499 & 7.3 & 4499 & 0.58 & 18,829 & 0.39 & [57] \\
\hline & Canada & Jul 2013- Dec 2015 & 4102 & 5.9 & 241 & 1.65 & 13,993 & 0 & [33] \\
\hline & $\begin{array}{l}\text { USA/ South } \\
\text { Caribbean }\end{array}$ & Unknown & 600 & 4.2 & 600 & 0.17 & $25^{\mathrm{b}}$ & 0 & [59] \\
\hline
\end{tabular}

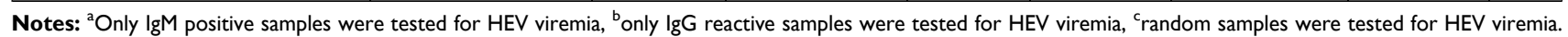

Additionally, a 10-fold serial dilution of the highest HEV RNA standard concentration was performed and tested in triplicates using the above-mentioned kit and thermocycler (Figure 1). The limit of detection of the kit was $0.1 \mathrm{IU} / \mathrm{ul}$ (Figure 1). The dilution of $0.01 \mathrm{IU} / \mathrm{ul}$ gave a positive RT-PCR result in one out of the three measurements at a Ct of 40.23 .

\section{Statistical Analysis}

All data were tabulated in Excel spreadsheets to calculate frequencies. The chi-square test was calculated using the OpenEPI webpage (https://www.openepi.com/Menu/OE

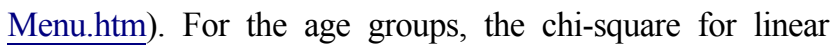

trend was used. The post-hoc analysis was used to calculate the chi-square for the difference among nationalities by testing each value of one nationality versus the sum value of all other nationalities. $\mathrm{P}$ value was considered significant if less than 0.05 .

\section{Results}

Of the 806 blood donors, 765 (94.91\%) were males and 41 $(5.08 \%)$ were females. $410(50.8 \%)$ of the blood donors were Saudis, while 396 (49.1\%) were non-Saudis from India, Yemen, Philippine, Egypt, Syria, Sudan, and Bangladesh (Table 2). Median age of the participants was 32 years (range $18-85$ years).

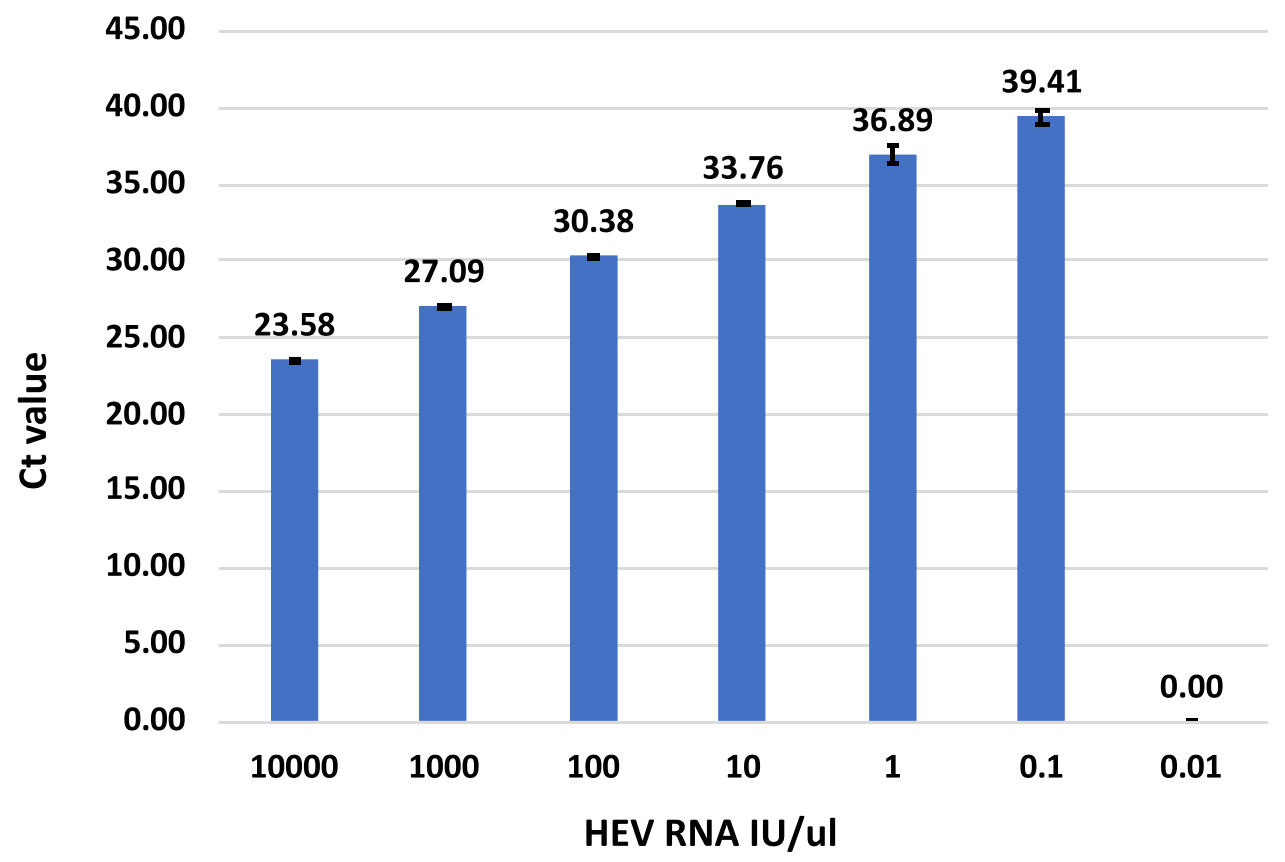

Figure I A I0-fold Serial dilution of HEV RNA detected by RealStar HEV RT-PCR Kit. The results show the average Ct from three measurements. The dilution 0.0I IU/ul gave a positive result in one out of the three readings with a $\mathrm{Ct}$ of 40.23 . 
Table 2 Prevalence of Anti-HEV IgG Antibodies Among Blood Donors in the Eastern Province of Saudi Arabia

\begin{tabular}{|c|c|c|c|c|c|c|}
\hline & \multicolumn{2}{|c|}{ Positive } & \multicolumn{2}{|c|}{ Negative } & \multirow[t]{2}{*}{ Total } & \multirow[t]{2}{*}{$P$ value } \\
\hline & $\mathbf{N}$ & $\%$ & $\mathbf{N}$ & $\%$ & & \\
\hline \multicolumn{7}{|l|}{ Gender } \\
\hline Male & 24 & 3.14 & $74 I$ & 96.86 & 765 & \multirow[t]{2}{*}{0.527} \\
\hline Female & 2 & 4.88 & 39 & 95.12 & 41 & \\
\hline \multicolumn{7}{|l|}{ Age groups } \\
\hline 18 to $<25$ & 5 & 3.76 & 128 & 96.24 & 133 & \multirow[t]{5}{*}{$0.589 *$} \\
\hline 25 to $<35$ & 10 & 2.90 & 336 & 97.1 & 346 & \\
\hline 35 to $<45$ & 8 & 3.96 & 194 & 96.04 & 202 & \\
\hline 45 to $<55$ & 3 & 3.16 & 92 & 96.84 & 95 & \\
\hline$\geq 55$ & 0 & 0 & 30 & 100 & 30 & \\
\hline \multicolumn{7}{|c|}{ Nationality** } \\
\hline Philippine & 2 & 6.25 & 30 & 93.75 & 32 & 0.356 \\
\hline Sudan & I & 5.26 & 18 & 94.74 & 19 & 0.589 \\
\hline Bangladesh & I & 5.26 & 18 & 94.74 & 19 & 0.589 \\
\hline India & 3 & 4.48 & 64 & 95.52 & 67 & 0.532 \\
\hline Egypt & 2 & 3.51 & 55 & 96.49 & 57 & 0.838 \\
\hline Saudi Arabia & 13 & 3.17 & 397 & 96.83 & 410 & 0.929 \\
\hline Syria & 1 & 2.27 & 43 & 97.73 & 44 & 0.906 \\
\hline Yemen & 2 & 2.04 & 96 & 97.96 & 98 & 0.522 \\
\hline Kuwait & 1 & 100 & 0 & 0 & I & 0.064 \\
\hline Others & 0 & 0 & 59 & 100 & 59 & 0.268 \\
\hline
\end{tabular}

Notes: *Chi square for linear trend. **The $\mathrm{p}$ value is calculated for each nationality against the sum of all other nationalities.

Anti-HEV IgG antibodies were detected by ELISA in $26(3.23 \%)$ donors, and there was no statistically significant difference between non-Saudis (3.28\%) and Saudis (3.17\%). Anti-HEV IgG antibodies were detected in $3.14 \%(24 / 765)$ of the males and in $4.88 \%(2 / 41)$ of the females with no statistically significant difference (Table 2). Additionally, there was no statistically significant tendency with different age groups.

The highest IgG antibody prevalence was observed among the blood donors from the Philippines followed by blood donors from Sudan, Bangladesh, India, Egypt, and Saudi Arabia (Table 2). One case was from Kuwait and was positive for HEV IgG. There was no statistically significant difference in the positivity among different nationalities (Table 2).
Anti-HEV IgM antibodies were not detected in any of the 26 samples IgG positive samples.

HEV-RNA was not detected in any of the 806 samples.

\section{Discussion}

In the current study, we tested 806 blood donors from the Eastern Province of Saudi Arabia for hepatitis E virus RNA, and HEV IgG and IgM antibodies. The seroprevalence for Anti-HEV IgG was found to be $3.23 \%$. None of the donors was positive for HEV RNA or Anti-HEV IgM. Additionally, there was no significant difference in $\mathrm{IgG}$ seroprevalence between Saudis (3.17\%) and non-Saudis (3.28\%) with any age or gender presence. Despite the fact that we have looked for IgM antibodies in IgG positive donors only, we believe that it is less likely to have missed IgM positive donors who are IgG negative for the following reason: According to the known information about the course of the HEV infection, IgM antibodies appear with the peak of RNA titer. ${ }^{63-65} \mathrm{IgG}$ antibodies appear at the peak of IgM antibodies and continue to be positive for a long time. IgM antibodies can still be detected until week 14 post-infection along with IgG antibodies. ${ }^{63-65}$ Therefore, there is no window where $\operatorname{IgG}$ antibodies are positive and IgM antibodies are negative during an acute infection and hence it is less likely that we have missed a patient with an acute infection because all patients were negative for RNA, and the IgG positive samples are negative for IgM. This means that all IgG positive blood donors in our study had past infections.

An approximately similar HEV IgG antibody prevalence was reported from another recent study from the middle region (Qasim) of Saudi Arabia (5.7\%). ${ }^{66}$ This is lower than the previously reported HEV IgG seroprevalence before 2013, where it ranged between $14 \%$ and $18 \%$ from the southern and western regions, respectively. ${ }^{16,42,43,67}$ This could indicate a reduction in the HEV exposure in the past few years or a regional difference in the country. The western region (Mecca and Jeddah) receives the majority of Saudi Arabia's visitors for religious purposes, who may import a silent infection and increase the exposure of the local population. Two studies have previously reported the detection of anti-HEV IgM antibodies without the confirmation of a current $\mathrm{HEV}$ infection with RNA detection. ${ }^{16,43}$ It is worth noting that HEV seroprevalence in countries of the expatriate who are involved in our study is also moderate, such as Philippines (11.8\%), Sudan (26\%), and Egypt (25\%). ${ }^{21,25,26}$

It is also important to note that the seroprevalence of Anti HEV-IgG in our study is less than neighboring 
Middle Eastern countries like Qatar (20.5\%) Iran (14.3\% and $11.5 \%)$, Egypt (25\%) and Abu-Dhabi (10.69\%) and African countries like Sudan (26\%), Ghana (4.6\%) and Asian countries from where most of the non Saudis belong to like Nepal (9.5\%) Pakistan (3.5\%) Philippines (11.8\%) China $(23.3 \%, 21.1 \%)$ Cambodia (28.2\%) Japan (3.7\%) and India $(17.70 \%$ and $60.5 \%)$ and European countries like Scotland $(4.7 \%, 6.1 \%)$ France $(3.94 \%$ and $52.5 \%) \quad$ Italy $(8.7 \%$ and $49 \%) \quad$ Netherland (26.7\%) Ireland (5.3\%) Spain (19.9\%) and Bulgaria (25.9\%). 15,17-21,23-26,29,30,35,36,44-48,50,51,53,54,58,59,68-70

However, this tremendous variation in seroprevalence among different countries is expected due to differences in assays, sample size and geography.

Our study was the first to look for HEV RNA in blood donors in the country. The lack of RNA detection in our study cannot be attributed to the reduced sensitivity of the employed RT-PCR kit, especially with the absence of IgM antibodies among the donors. Our analytical sensitivity analysis shows that the kit can detect as low as $0.1 \mathrm{IU} / \mathrm{ul}$ of HEV RNA consistently in three different measurements. This could, however, suggest the need for a much larger sample size to detect such a low prevalent virus. Additionally, a short duration of HEV viremia during the course of infection could have been missed by our one-time sampling strategy.

Transfusion-transmitted hepatitis $\mathrm{E}$ is gaining growing attention, particularly among blood donors, because of the increased number of reported cases in multiple countries. More importantly, HEV infections in high-risk individuals, such as pregnant women, immunocompromised patients and patients with hematological diseases, have been associated with fulminant hepatitis and chronic hepatitis, which can lead to liver cirrhosis and liver failure with high fatality. Furthermore, vertical transmission in pregnant women has been reported with high risk of transmission and high neonatal fatality. ${ }^{71,72}$

In response to the emerging pattern of transfusiontransmitted hepatitis E, screening programs for HEV in blood donors are being implemented in many countries including Austria, the Netherland, Ireland, UK, France, Spain, Germany, Luxembourg, ${ }^{73,74}$ Switzerland $^{76}$ and $\operatorname{Japan}^{75}$ and being evaluated in others. Hepatitis E screening programs for blood donors have been implemented using different modalities, which include universal screening vs selective screening and individual vs pooled samples screening. ${ }^{77}$ Cost-effectiveness studies showed variable impact ${ }^{78,79}$ primarily due to variations in $\mathrm{HEV}$ prevalence in different parts of the world.
This study reports a low seroprevalence of HEV in the blood donor population in the eastern province of Saudi Arabia and no detectable HEV viremia, which alone cannot rule out the risk of transfusion associated with hepatitis $\mathrm{E}$ in the area, particularly for high-risk individuals. One main limitation of this study is the sample size, which contributes to the lack of detection of HEV viremia and this necessitates the need for large-scale studies and evaluation of the cost-effectiveness of blood donor HEV screening programs in the kingdom in order to quantify the risk and propose a cost-effective preventive tool.

\section{Acknowledgments}

We are grateful to Mr. Lauro Bartolome for his technical support. We would also like to thank the technical staff of the blood bank at King Fahd Hospital of the University for their help in sample collection and the blood donors for their participation in the study. This project was funded by the Deanship of Research at Imam Abdulrahman Bin Faisal University (Project number: 2020-183-Med).

\section{Disclosure}

The authors report no conflicts of interest in this work.

\section{References}

1. Purdy MA, Harrison TJ, Jameel S, et al. ICTV virus taxonomy profile: hepeviridae. J Gen Virol. 2017;98(11):2645-2646. doi:10.1099/jgv.0. 000940

2. Kamar N, Dalton HR, Abravanel F, Izopet J. Hepatitis E virus infection. Clin Microbiol Rev. 2014;27(1):116-138. doi:10.1128/ CMR.00057-13

3. Lu L, Li C, Hagedorn CH. Phylogenetic analysis of global hepatitis E virus sequences: genetic diversity, subtypes and zoonosis. Rev Med Virol. 2006;16(1):5-36. doi:10.1002/rmv.482

4. Tsachev I, Baymakova M, Marutsov P, et al. Seroprevalence of hepatitis $\mathrm{E}$ virus infection among wild boars in western Bulgaria. Vector Borne Zoonotic Dis. 2021;21(6):441-445. doi:10.1089/ vbz.2020.2756

5. Jemeršić L, Prpić J, Brnić D, Keros T, Pandak N, Đaković Rode O. Genetic diversity of hepatitis $\mathrm{E}$ virus (HEV) strains derived from humans, swine and wild boars in Croatia from 2010 to 2017. BMC Infect Dis. 2019;19(1):269. doi:10.1186/s12879-019-3906-6

6. ICTV Report. Genus: Orthohepevirus - Hepeviridae - Positive-sense RNA Viruses - ICTV. Published 2021. Available from: https://talk. ictvonline.org/ictv-reports/ictv_online_report/positive-sense-rnaviruses/w/hepeviridae/728/genus-orthohepevirus. Accessed August 22, 2021.https://talk.ictvonline.org/ictv-reports/ictv_online_report/posi tive-sense-rna-viruses/w/hepeviridae/728/genus-orthohepevirus

7. Hewitt PE, Ijaz S, Brailsford SR, et al. Hepatitis E virus in blood components: a prevalence and transmission study in southeast England. Lancet. 2014;384(9956):1766-1773. doi:10.1016/S01406736(14)61034-5

8. Pallerla SR, Harms D, Johne R, et al. Hepatitis E virus infection: circulation, molecular epidemiology, and impact on global health. Pathogens. 2020;9(10):856. doi:10.3390/pathogens9100856 
9. Khuroo MS, Khuroo MS, Khuroo NS. Transmission of hepatitis E virus in developing countries. Viruses. 2016;8(9):253. doi:10.3390/v8090253

10. Khuroo MS, Kamili S, Yattoo GN. Hepatitis E virus infection may be transmitted through blood transfusions in an endemic area. J Gastroenterol Hepatol. 2004;19(7):778-784. doi:10.1111/j.14401746.2004.03437.x

11. Al-Fawaz I, Al-Rasheed S, Al-Mugeiren M, Al-Salloum A, AlSohaibani M, Ramia S. Hepatitis E virus infection in patients from Saudi Arabia with sickle cell anaemia and $\beta$-thalassemia major: possible transmission by blood transfusion. J Viral Hepat. 1996;3 (4):203-205. doi:10.1111/j.1365-2893.1996.tb00096.x

12. Hoad VC, Gibbs T, Ravikumara M, et al. First confirmed case of transfusion-transmitted hepatitis E in Australia. Med J Aust. 2017;206 (7):289-290. doi:10.5694/mja16.01090

13. Kyodo.The Japan Times.2018.In world first, woman's death linked to hepatitis E infection after blood transfusion at Japanese facility. The Japan Times. Available from: https://www.japantimes.co.jp/news/ 2018/02/01/national/world-first-womans-death-linked-hepatitis -e-infection-blood-transfusion-japanese-facility/. Accessed May 6, 2021.

14. World Health Organization. Global status report on blood safety and availability, 2016; 2017. Available from: http://apps.who.int/iris/bit stream/10665/254987/1/9789241565431-eng.pdf. Accessed April 10, 2021.

15. Marcantonio C, Pezzotti P, Bruni R, et al. Incidence of hepatitis $\mathrm{E}$ virus infection among blood donors in a high endemic area of Central Italy. J Viral Hepat. 2019;26(4):506-512. doi:10.1111/ jvh.13049

16. Alhatlani BY, Aljabr WA, Almarzouqi MS, et al. Seroprevalence of the hepatitis E virus among blood donors in the Qassim Region, Saudi Arabia. medRxiv. 2019;2019:12.19.19015412. doi:10.1101/ 2019.12.19.19015412

17. Ali IAO. Supervisor -Humodi Ahmed Saeed. Seroprevalence of hepatitis e virus among blood donors in Sheikh Khalifa Medical City, Abu Dhabi, United Arab Emirates; 2015. Available from: http://repository.sustech.edu//handle/123456789/13162. Accessed March 30, 2021.

18. Nasrallah GK, Absi ESA, Ghandour R, et al. Seroprevalence of hepatitis E virus among blood donors in Qatar (2013-2016). Transfusion. 2017;57(7):1801-1807. doi:10.1111/trf.14116

19. Ehteram H, Ramezani A, Eslamifar A, et al. Seroprevalence of hepatitis $\mathrm{E}$ virus infection among volunteer blood donors in central province of Iran in 2012. Iran J Microbiol. 2013;5(2):172-176.

20. Assarehzadegan MA, Shakerinejad G, Amini A, Rezaee SAR. Seroprevalence of hepatitis E virus in blood donors in Khuzestan Province, Southwest Iran. Int J Infect Dis. 2008;12(4):387-390. doi:10.1016/j.ijid.2007.09.015

21. Ibrahim EH, Abdelwahab SF, Nady S, et al. Prevalence of anti-HEV IgM among blood donors in Egypt. Egypt $J$ Immunol. 2011;18 (2):47-58.

22. Al-Kasaby NM, Zaki MES. Study of hepatitis E virus in blood donors. Open Microbiol J. 2019;13(1):285-291. doi:10.2174/187428 5801913010285

23. Gupta BP, Lama TK, Adhikari A, et al. First report of hepatitis $\mathrm{E}$ virus viremia in healthy blood donors from Nepal. Virusdisease. 2016;27(3):324-326. doi:10.1007/s13337-016-0331-y

24. Saba N, Waheed U, Mohammad I, Wazeer A. Hepatitis E virus RNA in Pakistani blood donors: An emerging transfusion transmitted infection. Glob J Transfus Med [serial online] 2020 [cited 2021 Aug 22];5:233. Available from: https:/www.gjtmonline.com/text.asp? 2020/5/2/233/300641.

25. Sia SG, De Guzman TS, Su GLS. Detection of IgM and IgG antibodies against hepatitis $\mathrm{E}$ virus in donated blood bags from a national voluntary blood bank in Metro Manila, Philippines. Asian Pac J Trop Dis. 2015;5(8):604-605. doi:10.1016/S2222-1808(15)60896-9
26. Ahmed AB. Seroprevalence of hepatitis E virus among blood donors in Omdurman locality, Sudan. Am J Res Commun. 2015;3 (5):252-258.

27. Hewitt J, Harte D, Sutherland M, et al. Prevalence of hepatitis E virus antibodies and infection in New Zealand blood donors. 2018;131 (1469):6.https://www.nzma.org.nz/journal-articles/prevalence-ofhepatitis-e-virus-antibodies-and-infection-in-new-zealand-blooddonors

28. Baylis SA, Gärtner T, Nick S, Ovemyr J, Blümel J. Occurrence of hepatitis E virus RNA in plasma donations from Sweden, Germany and the United States. Vox Sang. 2012;103(1):89-90. doi:10.1111/ j.1423-0410.2011.01583.x

29. Cleland A, Smith L, Crossan C, et al. Hepatitis E virus in Scottish blood donors. Vox Sang. 2013;105(4):283-289. doi:10.1111/vox.12056

30. Thom K, Gilhooly P, McGowan K, et al. Hepatitis E virus (HEV) in Scotland: evidence of recent increase in viral circulation in humans. Euro Surveill. 2018;23(12):12. doi:10.2807/1560-7917.ES.2018.23. 12.17-00174

31. Corman VM, Drexler JF, Eckerle I, Roth WK, Drosten C, EisHübinger AM. Zoonotic hepatitis E virus strains in German blood donors. Vox Sang. 2013;104(2):179-180. doi:10.1111/j.1423-0410.20 12.01638.x

32. Vollmer T, Diekmann J, Johne R, Eberhardt M, Knabbe C, Dreier J. Novel approach for detection of hepatitis E virus infection in German blood donors. J Clin Microbiol. 2012;50(8):2708. doi:10.1128/ JCM.01119-12

33. Fearon MA, O'Brien SF, Delage G, et al. Hepatitis E in Canadian blood donors. Transfusion. 2017;57(6):1420-1425. doi:10.1111/ trf. 14089

34. Fischer C, Hofmann M, Danzer M, Hofer K, Kaar J, Gabriel C. Seroprevalence and incidence of hepatitis $\mathrm{E}$ in blood donors in Upper Austria. PLoS One. 2015;10(3):e0119576. doi:10.1371/journal.pone.0119576

35. Gallian P, Lhomme S, Piquet Y, et al. Hepatitis E virus infections in blood donors, France. Emerg Infect Dis. 2014;20(11):1914-1917. doi:10.3201/eid2011.140516

36. Mansuy J-M, Bendall R, Legrand-Abravanel F, et al. Hepatitis E virus antibodies in blood donors, France. Emerg Infect Dis. 2011;17(12):2309-2312. doi:10.3201/eid1712.110371

37. Harritshøj LH, Holm DK, Sækmose SG, et al. Low transfusion transmission of hepatitis $\mathrm{E}$ among 25,637 single-donation, nucleic acid-tested blood donors. Transfusion. 2016;56(9):2225-2232. doi:10.1111/trf.13700

38. Shrestha AC, Flower RLP, Seed CR, et al. Hepatitis E virus RNA in Australian blood donations. Transfusion. 2016;56(12):3086-3093. doi:10.1111/trf.13799

39. Hogema BM, Molier M, Sjerps M, et al. Incidence and duration of hepatitis $\mathrm{E}$ virus infection in Dutch blood donors. Transfusion. 2016;56(3):722-728. doi:10.1111/trf.13402

40. Slot E, Hogema BM, Riezebos-Brilman A, Kok TM, Molier M, Zaaijer HL. Silent hepatitis E virus infection in Dutch blood donors, 2011 to 2012. Eurosurveillance. 2013;18(31):20550. doi:10.2807/ 1560-7917.ES2013.18.31.20550

41. Intharasongkroh D, Thongmee T, Sa-nguanmoo P, et al. Hepatitis E virus infection in Thai blood donors. Transfusion. 2019;59 (3):1035-1043. doi:10.1111/trf.15041

42. Abdelaal M, Zawawi TH, Al Sobhi E. Epidemiology of hepatitis $\mathrm{E}$ virus in male blood donors in Jeddah, Saudi Arabia. IJMS. 1998;167(2):94. doi:10.1007/BF02937946

43. Johargy AK, Mahomed MF, Khan MM, Kabrah S. Anti hepatitis $\mathrm{E}$ virus seropositivity in a group of male blood donors in Makkah, Saudi Arabia. J Pak Med Assoc. 2013;63(2):185-189.

44. Katiyar H, Goel A, Sonker A, et al. Prevalence of hepatitis E virus viremia and antibodies among healthy blood donors in India. Indian J Gastroenterol. 2018;37(4):342-346. doi:10.1007/s12664-0180880-7 
45. Tripathy AS, Puranik S, Sharma M, Chakraborty S, Devakate UR Hepatitis E virus seroprevalence among blood donors in Pune, India. $J$ Med Virol. 2019;91(5):813-819. doi:10.1002/jmv.25370

46. Lucarelli C, Spada E, Taliani G, et al. High prevalence of anti-hepatitis $\mathrm{E}$ virus antibodies among blood donors in central Italy, February to March 2014. Eurosurveillance. 2016;21 (30):30299. doi:10.2807/1560-7917.ES.2016.21.30.30299

47. Spada E, Pupella S, Pisani G, et al. A nationwide retrospective study on prevalence of hepatitis $\mathrm{E}$ virus infection in Italian blood donors. Blood Transfus. 2018;16(5):413-421. doi:10.2450/2018.0033-18

48. Guo Q-S, Yan Q, Xiong J-H, et al. Prevalence of hepatitis E virus in Chinese blood donors. J Clin Microbiol. 2010;48(1):317-318. doi:10.1128/JCM.01466-09

49. Ma L, Sun P, Lin F, et al. Prevalence of hepatitis E virus in Chinese blood donors. J Int Med Res. 2015;43(2):257-262. doi:10.1177/ 0300060514562054

50. Zhuang W, Ding X, Lyu C, Xiang L, Teng H, Li J. Hepatitis E virus seroprevalence among blood donors in Jiangsu Province, East China. International Journal of Infectious Diseases. 2014;26:9-11. doi:10.1016/j.ijid.2014.04.022https://www-clinicalkey-com.library. iau.edu.sa/\#!/content/playContent/1-s2.0-S1201971214015185?retur nurl=https: $\% 2 \mathrm{~F} \% 2$ Flinkinghub.elsevier.com $\% 2$ Fretrieve $\% 2 \mathrm{Fpii} \%$ 2FS1201971214015185\%3Fshowall\%3Dtrue\&referrer=

51. Meldal BHM, Sarkodie F, Owusu-Ofori S, Allain J-P. Hepatitis $\mathrm{E}$ virus infection in Ghanaian blood donors - The importance of immunoassay selection and confirmation. Vox Sang. 2013;104 (1):30-36. doi:10.1111/j.1423-0410.2012.01637.x

52. Minagi T, Okamoto H, Ikegawa M, et al. Hepatitis E virus in donor plasma collected in Japan. Vox Sang. 2016;111(3):242-246. doi:10.1111/vox.12425

53. Nouhin J, Prak S, Madec Y, et al. Hepatitis E virus antibody prevalence, RNA frequency, and genotype among blood donors in Cambodia (Southeast Asia). Transfusion. 2016;56(10):2597-2601. doi:10.1111/trf.13731

54. O'Riordan J, Boland F, Williams P, et al. Hepatitis E virus infection in the Irish blood donor population. Transfusion. 2016;56(11):28 68-2876. doi:10.1111/trf.13757

55. Petrović T, Lupulović D, Jiménez de Oya N. Prevalence of hepatitis E virus (HEV) antibodies in Serbian blood donors. J Infect Dev Ctries. 2014;8(10):1322-1327. doi:10.3855/jidc.4369

56. Roth NJ, Schäfer W, Alexander R, et al. Low hepatitis E virus RNA prevalence in a large-scale survey of United States source plasma donors. Transfusion. 2017;57(12):2958-2964. doi:10.1111/trf.14285

57. Stramer SL, Moritz ED, Foster GA, et al. Hepatitis E virus: seroprevalence and frequency of viral RNA detection among US blood donors. Transfusion. 2016;56(2):481-488. doi:10.1111/trf.13355

58. Sauleda S, Ong E, Bes M, et al. Seroprevalence of hepatitis E virus (HEV) and detection of HEV RNA with a transcription-mediated amplification assay in blood donors from Catalonia (Spain). Transfusion. 2015;55(5):972-979. doi:10.1111/trf.12929

59. Schreuder I, Limper M, Gerstenbluth I, et al. Hepatitis E virus infection among blood donors in the South Caribbean: is screening warranted? Neth J Med. 2016;74(1):51-53.

60. Abbexa. Abbexa - Antibodies, Proteins, ELISA kits. Abbexa. Published 2021. Available from: https://www.abbexa.com/hepatitise-virus-igg-elisa-kit. Accessed August 22, 2021.

61. Abbexa - Antibodies, Proteins, ELISA kits. Abbexa. Available from: https://www.abbexa.com/human-hepatitis-e-virus-antibody-igm-elisakit-1. Accessed August 22, 2021.

62. RealStar HEV RT-PCR Kit 2.0_WEB_CE_EN-S01.pdf. Available from: https://www.altona-diagnostics.com/files/public/Content $\%$ 20Homepage/-\%2002\%20RealStar/MAN\%20-\%20CE\%20-\%20EN/ RealStar\%20HEV\%20RT-PCR\%20Kit\%202.0_WEB_CE_EN-S01. pdf. Accessed April 5, 2021.
63. Lhomme S, Marion O, Abravanel F, Chapuy-Regaud S, Kamar N, Izopet J. Hepatitis E Pathogenesis. Viruses. 2016;8(8):212. doi: $10.3390 / \mathrm{v} 8080212$

64. Pelosi E, Clarke I. Hepatitis E: a complex and global disease. Emerg Health Threats J. 2008;1:e8. doi:10.3134/ehtj.08.008

65. Webb GW, Dalton HR. Hepatitis E: an underestimated emerging threat. Ther Adv Infect. 2019;6:2049936119837162. doi:10.1177/ 2049936119837162

66. Alhatlani BY, Aljabr WA, Almarzouqi MS, et al. Seroprevalence of the hepatitis E virus antibodies among blood donors in the Qassim region, Saudi Arabia. Future Virol. 2021;16(6):383-388. doi:10.2217/ fvl-2021-0013

67. Arif M, Qattan I, Al-Faleh F, Ramia S. Epidemiology of hepatitis E virus (HEV) infection in Saudi Arabia. Ann Trop Med Parasitol. 1994;88(2):163-168. doi:10.1080/00034983.1994.11812854

68. Fukuda S, Sunaga J, Saito N, et al. Prevalence of antibodies to hepatitis $\mathrm{E}$ virus among Japanese blood donors: identification of three blood donors infected with a genotype 3 hepatitis $\mathrm{E}$ virus. $J$ Med Virol. 2004;73(4):554-561. doi:10.1002/jmv.20125

69. Mansuy JM, Sauné K, Rech H, et al. Seroprevalence in blood donors reveals widespread, multi-source exposure to hepatitis E virus, southern France, October 2011. Eurosurveillance. 2015;20(19):21127. doi:10.2807/1560-7917.ES2015.20.19.21127

70. Baymakova M, Terzieva K, Popov R, et al. Seroprevalence of hepatitis $\mathrm{E}$ virus infection among blood donors in Bulgaria. Viruses. 2021;13(3):492. doi:10.3390/v13030492

71. Kumar RM, Uduman S, Rana S, Kochiyil JK, Usmani A, Thomas L. Sero-prevalence and mother-to-infant transmission of hepatitis E virus among pregnant women in the United Arab Emirates. Eur J Obstet Gynecol Reprod Biol. 2001;100(1):9-15. doi:10.1016/ S0301-2115(01)00448-1

72. Khuroo MS, Kamili S, Khuroo MS. Clinical course and duration of viremia in vertically transmitted hepatitis E virus (HEV) infection in babies born to HEV-infected mothers. J Viral Hepat. 2009;16 (7):519-523. doi:10.1111/j.1365-2893.2009.01101.x

73. Boland F, Martinez A, Pomeroy L, O'Flaherty N. Blood Donor Screening for Hepatitis E Virus in the European Union. TMH. 2019;46(2):95-103. doi:10.1159/000499121https://pubmed-ncbinlm-nih-gov.library.iau.edu.sa/31191195/

74. Domanović D, Tedder R, Blümel J, et al. Hepatitis E and blood donation safety in selected European countries: a shift to screening? Eurosurveillance. 2017;22(16):30514. doi:10.2807/1560-7917.ES.20 17.22.16.30514

75. Niederhauser C, Widmer N, Hotz M, et al. Current hepatitis E virus seroprevalence in Swiss blood donors and apparent decline from 1997 to 2016. Euro Surveill. 2018;23(35):1700616. doi:10.2807/ 1560-7917.ES.2018.23.35.1700616

76. Matsubayashi K, Sakata H, Ikeda H. Hepatitis E virus infection and blood transfusion in Japan. ISBT Sci Ser. 2011;6(2):344-349. doi:10.1111/j.1751-2824.2011.01512.x

77. Bi H, Yang R, Wu C, Xia J. Hepatitis E virus and blood transfusion safety. Epidemiol Infect. 2020;148:e158. doi:10.1017/S0950268820001429

78. De vos AS, Janssen MP, Zaaijer HL, Hogema BM. Cost-effectiveness of the screening of blood donations for hepatitis $E$ virus in the Netherlands. Transfusion. 2017;57(2):258-266. doi:10.1111/trf.13978

79. Delage G, Fearon M, Gregoire Y, et al. Hepatitis E virus infection in blood donors and risk to patients in the United States and Canada. Transfus Med Rev. 2019;33(3):139-145. doi:10.1016/j.tmrv.2019.05.017

80. Zhuang W, Ding X, Lyu C, Xiang L, Teng H, Hepatitis LJ. E virus seroprevalence among blood donors in Jiangsu Province, East China. Int J Infect Dis. 2014;26:9-11. doi:10.1016/j.ijid.2014.04.022

81. Hoad VC, Seed CR, Fryk JJ, et al. Hepatitis E virus RNA in Australian blood donors: prevalence and risk assessment. Vox Sang. 2017;112(7):614-621. doi:10.1111/vox.12559 


\section{Publish your work in this journal}

The Journal of Multidisciplinary Healthcare is an international, peerreviewed open-access journal that aims to represent and publish research in healthcare areas delivered by practitioners of different disciplines. This includes studies and reviews conducted by multidisciplinary teams as well as research which evaluates the results or conduct of such teams or healthcare processes in general. The journal covers a very wide range of areas and welcomes submissions from practitioners at all levels, from all over the world. The manuscript management system is completely online and includes a very quick and fair peer-review system. Visit http://www.dovepress.com/testimonials. php to read real quotes from published authors. 